\title{
Capital and ressentiment: The totalizing power of social fragmentation
}

\section{Joseph Vogl}

Humboldt University of Berlin, Germany/Princeton University, USA

\section{Editors' note}

Joseph Vogl's new book, Capital and Ressentiment (2021/2022), traces an epistemic shift from knowledge to information driven by the convergence of financialization and the platform economy. As a variable that is determined less by semantic content than by difference to existing expectations, information invites indifference to other distinctions, such as those between fact and fiction, claim and proof. The circulation of information takes the form of opinion markets wherein the production of reality itself is at stake. In this extract, taken from the book's final chapter, "The cunning of ressentiment-driven reason", Vogl analyses populist ressentiment as both structural affect of and vital resource for information capitalism, laying out the resulting reconfiguration of the social.

\begin{abstract}
$* * *$
Parallel to this [Karl Marx's notion of the "abstract hedonism" of the capitalist, a boundless desire that cannot be met by any concrete need or episodic satisfaction], since the second half of the nineteenth century, a similar affect and a related lack-in-being (Seinsmangel) have been discovered in the conceptual formation of ressentiment. ${ }^{1}$ Contemporary analyses [by Kierkegaard, Nietzsche, Werner Sombart, and Max Scheler] sought to relate this principle directly to the epoch of expanding capital and finance economy in Europe, to emerging liberalism, to the structure of bourgeois society, to the dynamics of periods of rapid growth, and to modern economic man as subject. Clearly, such perspectives have themselves not always been free of ressentiment and - like Sombart's anti-Semitism or Scheler's world-war nationalism - recommend a critical interpretation of these ressentiment critiques themselves. Nonetheless, they still lay out a trail that points to an effective, reciprocal relationship between instances of ressentiment and capitalism. In this context, one should first call to mind some elements that, since Nietzsche, have been essential for characterizing structures of ressentiment and have persisted across diverging analyses and standpoints.
\end{abstract}

\section{Corresponding author:}


This includes, first, a peculiarly broken self-affirmation of the subject of ressentiment, which takes place only as the result of an unconditional "no" to an "outside", to an "other", to a "not-self", and thus derives from a negation. Second, this inversion of a negation into a negating self-affirmation is connected to a shift of forces, in which action is replaced by reaction and the latter by inhibition. This leads to a passive form of activity, to a forced or selfimposed block of action, and thus to a cultivation of powerlessness. The "re-" in ressentiment (French se ressentir de qc.: to sense the aftereffects or consequences of something) signals that blocked (re)actions have congealed into a permanent and unresolved state of mind. Third, this means that the objects and entities of the external world can become, in varying degrees, possible occasions for a felt grievance and injury, for the pain of being rejected. They can make themselves felt with an existential or life envy and with a burning sense of a lack-in-being, with memory serving as a self-reinforcing mechanism for such suffering. And this diminishment of being is not just linked to an inversion of the valorizing gaze, an inversion that itself becomes creative and produces values. It is also linked to a tendency to delegate, to an interest in turning over domains of activity, to a kind of punitivism that appeals to higher powers and instances for the harming or taming of others. Fourth and finally, a concretism is invoked, a preference for what are assumed to be immediately tangible embodiments, with which one makes attributions and assigns responsibility, sets one's own disadvantages against other people's advantages, identifies culprits, and even personalizes what may very well be due to "circumstances": "Someone must be to blame for the fact that I am in a bad way". ${ }^{2}$ Causal reflexes and bits of evidence are privileged over real causal research; ressentiment cannot cope with the uncertainty of causes. [...]

[If one considers] ressentiment not as a subjective mood or mental state, but rather as a structure of relations and a mode of communication, taking it in its systemic and systematic dimension, [it] becomes clear that its roots, its flashpoint, and its primary capital lie in a specific compulsion to compare and relate, in a reflex to valorize and evaluate, in a rampant desire to judge. [...] In several respects, then, a functional relationship between capitalism and ressentiment can be observed that encompasses, in equal measure, formal conditions, modes of social intercourse, subject forms, and judgment practices. Moreover, this structural affective-economic connection has repeatedly been supplemented and reinforced by conspicuous cyclical movements [that arise in particular at times of financial crisis]. [...]

In this context [...], the mechanism of ressentiment follows a course that is as peculiar as it is exemplary. For example, the financial panics after 1870 were followed by an expansion and intensification of anti-Semitism - all the way to the emergence of anti-Semitic political parties. Here, we find an initial articulation of the cunning of ressentiment-driven reason as it consistently distracted from the immanent purposes of the economic system, and from the effectiveness of its apparatuses, infrastructures, and functional mechanisms. It found its need for the concretization of attribution, responsibility, and causation satisfied with the personification of the economic system in representatives of so-called high finance, ultimately targeting the figure of the "greedy" Jewish finance capitalist. (To this day, and in various guises, the attractive "greed" of overly greedy speculators has, after all, assumed a comparable intellectual exculpatory function). [...]

By means of anti-Semitism in the last third of the nineteenth century, then, the cunning of ressentiment-driven reason dramatizes itself, and the alliance between capital and race forged in this way - in conjunction with the exorcism of "unproductive" finance capital woven into anti-Semitism - proves to be the conformist insurgency of ressentiment. Combined, these forces ultimately prove to be an efficient capitalist self-criticism, with which the economic system is able to ensure its survival in times of crisis. The system's conditions themselves 
remain unexamined.

Ressentiment can thus be understood as a stabilizing and structural basic affect of capitalism that undergoes special cycles under the contemporary finance economy and its crises. However, the management of the social by finance and information capital has provided this intertwining of affect communication and economic dynamics with a recent twist and intensification. [...]

Thus, the platform industry's claim to hegemony - as with Facebook - is apparently directed at organizing collective decision-making power apart from and alongside established political procedures. This is the fabrication of a special version of digital "neocommunities" (Reckwitz, 2020: 188-94), whose supply scheme consists not least in facilitating seemingly authentic direct communications on the basis of highly selective technical mediation procedures. The complex media operations of the opinion brokers are designed to generate phobias against all mediating entities. The political character of such techno-social infrastructures shows itself in four aspects. It is seen first in the phantasm of immediate access to the addresses of political power, which accordingly manifests itself in exclusive private relations and demands participation through acclamation - everyone is addressed and heard at the same time.

It is seen secondly in an informalization of the transfer and exercise of political power, which is accomplished by cutting out mediating entities and, in particular, by stigmatizing the formal character of representative institutions as false or falsifying, be they elections or parliaments, "elites" or the press.

It is seen thirdly through the activation of nonspecific social ensembles and entities such as "communities", "humanity", “people", "us", "[a] coming together", or "meaningful groups". They do not take on any representative form and at best make themselves noticeable through a conspicuous eventfulness in their collective movements and impulses. This is a "metapolitical fiction" 3 of indefinite and diffuse community forces, which can be activated and concentrated by different collective identities. Then, via the procedures of algorithmic tribalization, the variants of a supposedly "authentic popular will" or various "political peoples" 4 also find their address and their place.

Fourthly and finally, the associated modes of reaction and rapid communications have a ballistic character, as it were; they are about targeting - about getting one's bearings, addressing, and hitting the target - in other words, about the perfecting of a communicative striking skill, which, with the use of news bullets or hashtag-bundled formations, probably possesses a prototype in the procedures of military enemy recognition: "Boom. I press it, ... and, within two seconds, "We have breaking news'”. ${ }^{5}$ [...]

\section{$* * *$}

Platforms and social media promise nothing less than an immediatization of political participation and action. However, even with these socio-technical preconditions, a dynamic propensity for ressentiment is only brought about under digital capitalism by the privileging of those opinion markets that define the business model of platform companies and have been made possible by Internet exceptionalism. In this context, one should probably consider the interplay of two factors. Thus, in the reciprocal relationship between economic dynamics and social or political ones, the form of opinion and of the opinion-like (des Meinungshaften) holds a special systemic position. For the scaling and algorithmic processing of information as well as the procedures for managing data only function under the condition that explanationresistant substrates are communicated. Accordingly, one subtracts from modes of expression 
the burden of proof, from preferences the justification, and from decisions the pressure for legitimation. The proximity to financial and stock markets also shapes this. Apart from the fact that financial industries and Internet or platform companies alike engage in data brokerage and pursue algorithmic market operations, they also share in common the establishment of feedback loops, automatic response cycles, and a machine-based evaluation of relevance (Latzer et al., 2016). Just as financial markets operate as opinion markets under the conditions of information technology, ${ }^{6}$ opinion markets on the platforms are conversely structured according to a finance-economic evaluation logic. [...]

Digital technologies and the information economy have produced a specific form of the social today that is characterized by the organization of disjunctive syntheses. Here, a general dynamic of normalization coincides with manifold processes of monadization or particularization, and converging and diverging regularities simultaneously determine the arrangement of social event series, leading not to a decrease but to an increase in elements of indifference or equivalent validations (Gleich-Gültigkeiten). It is, namely, precisely through the generation and reinforcement of conformities (Konformismen) that social powers of divergence are stimulated. This constellation, however, cannot simply be grasped as a "crisis of the general", conditioned by a new upswing of social, political, and cultural singularities in current forms of society (cf. Reckwitz, 2020: 310-19; Terzić, 2022). It is much more about the way in which the relations between the processes of generalization and particularization are interconnected and have undergone a specific and critical turn under the dominance of finance and information capitalism. [If] recent considerations in democracy theory envision an open process that, starting from particular social identities, strives toward a universal horizon [where] the self-seclusion of the particular is to be undermined just as rigorously as the permanent occupation of the universal by particular interests, an opposite movement is taking place under the logic of information capital. The generality of codes and information is thereby confronted by a process that culminates in self-contained social monads, and the universalization of information capital is guaranteed precisely by producing unconnected particularities. Thus, it is no longer a matter of how particular identities open up and pluralize - democratically - toward a universal horizon, but, conversely, of how globally effective capital movements bring about an "idiocratic" 7 intensification of power relations and reproduce themselves by producing - anti-democratically - divergent, competing, and conflicting particularities (Terzic, 2022). Through the production of plural self-contained entities, pluralistic spaces of action are cut off and undermined.

Therefore - under a supposed immediatization of (political) communications - unfiltered and, as it were, ethereal relations between leader and follower, as well as the repudiation of mediating instances, are linked in the platform economy with a mobilization of collective forces. The knowability of these collective forces manifests itself in immediate modes of response and in the absorption of potentials for stimulation and movement. At the same time, the privileging of the form of the opinion in the operation of social media and platforms has led to more than just a repudiation of zones of reflection and scenarios of reasoning, as well as to a quasi-ballistic form of rapid communication. It has also led to a dual and opposing tendency in which the universalization of information standards coincides with an efficient monadization of user communities. Alongside the generalized establishment of competitive venues and the dissolution of milieus of solidarity in contemporary market societies, the economic dynamics and business models of information capitalism have thus created specific conditions or architectures in which, with structural populism, ressentiment has become an integral part of the capitalist economy of affect. In it, it functions both as a product and as a productive force, and contributes, particularly with its corrosive political and social forces, to the stabilization of 
the economic system of finance capitalism. Thus, the economy of ressentiment [...] generates circumscribed domains of experience, multiplies the number of segregated pseudocommunities, and privileges plebiscitarian, authoritarian figures. Moreover, it turns the anxiety caused by global markets, transnational interventionist forces, and economic dependencies into tangible denunciatory formulas that can then refer equally to, say, the border transgressions of migrants, European bureaucrats, greedy investors, or conspirators in the financial industry.

The critique festering in ressentiment always takes policing as its method: it searches and suspects and seeks out surrogate objects that are concretely tangible and supposedly liable for the efficacy of abstract system processes - whereas critique should actually move in the opposite direction, advancing from tangible and concrete instances to the conditions of their production. On the one hand, the cunning of ressentiment has thus provided an answer to the question of how the valorization of fragmentation, parcellation, diversity, and contingency benefits global finance and information capital in such a way that it can neither be understood nor attacked as a totalizing power (Dean, 2002: 8). It is precisely the centrifugal forces of separate worlds and communities that have obscured the view of the conformist production of the real. On the other hand, this has brought about the most recent radicalization of negative socialization, in which particularities are related to particularities, following a divisive principle and - as Kierkegaard would have said - coming together in the negative unity of negative reciprocity. The private-public alliances under the governance of the finance economy are supplemented by the production of authoritarian social structures along the lines of the information industry. Even if history has no endings and never reaches a point of utter hopelessness, it must be conceded that the hostility of all against all has become not only a successful business model, but has also created an extremely sustainable sense of community. It is not impossible that it will provide the ferment for a new prewar era.

\section{Notes}

1. This extract is taken from the pre-published translation by Neil Solomon of "Die List der ressentimentalen Vernunft", the concluding chapter in Kapital und Ressentiment (Vogl, 2021: 157-82). The English translation of the entire book will be published by Polity Press next year as Capital and Ressentiment (Vogl, 2022). Small adjustments have been made to the paragraphing.

2. See Nietzsche, 1989: 36-37, 127; Nietzsche, 1990: 50-51; Scheler, 1961: 43-49; Sartre, 1981: 386-409; Deleuze, 2006: 111-19; and Olschanski, 2015: 15-50.

3. Hans Kelsen, quoted in Müller, 2016: 58.

4. Ibid. 56-57.

5. According to a remark by the last U.S. president; see New York Times, 2019. For this reason, demands for the introduction of frictions, delays, and interruptions in network communication seem extremely plausible; cf. Forum on Information and Democracy, 2020.

6. Vogl, 2021: 53-58.

7. Perhaps the term "plutocratic populism" would also be appropriate, insofar as mechanisms of tribalization are linked to strategies of enrichment; cf. Hacker and Pierson, 2020: 5.

\section{References}

Dean, J. (2002) Publicity's Secret: How Technoculture Capitalizes on Democracy. Ithaca, NY: Cornell University Press. 
Deleuze, D. (2006) Nietzsche and Philosophy, translated by H. Tomlinson. New York: Continuum. Forum on Information and Democracy (2020) Working Group on Infodemics: Policy Framework.

Available at: <https://informationdemocracy.org/wp-content/uploads/2020/11/ForumID_Reporton-infodemics_101120.pdf>.

Hacker, J.S and Pierson, P. (2020) Let them Eat Tweets: How the Right Rules in an Age of Extreme Inequality. New York: Liveright Publishing.

Latzer, M., Hollnbuchner, K., Just, N. and Saurwein, F. (2016) The economics of algorithmic selection on the Internet. In: Bauer, J.M. and Latzer, M. (eds.) Handbook on the Economics of the Internet. Cheltenham: Edward Elgar, 395-425.

Müller, J.-W. (2016) Was ist Populismus? Ein Essay. Frankfurt am Main: Suhrkamp.

New York Times (2019) How Trump reshaped the presidency in over 11,000 tweets. The New York Times, 2 November. Interactive website, https://nyti.ms/32aaAbV.

Nietzsche, F. (1989) On the genealogy of morals. In: On the Genealogy of Morals and Ecce Homo, translated by W. Kaufmann and R.J. Hollingdale. New York: Vintage, 13-163.

Nietzsche, F. (1990) Twilight of the idols or how to philosophize with a hammer. In: Twilight of the Idols and the Anti-Christ, translated by R.J. Hollingdale. New York: Penguin, 29-122.

Olschanski, R. (2015) Ressentiment: Über die Vergiftung des europäischen Geistes. Paderborn: Wilhelm Fink.

Reckwitz, A. (2020) The Society of Singularities, translated by V.A. Pakis. Cambridge: Polity Press.

Sartre, J.-P. (1981) Father and son: F. resentment. In: The Family Idiot: Gustave Flaubert, 1821-1857, vol. 1, trans. C. Cosman. Chicago, IL: University of Chicago Press.

Scheler, M. (1961) Ressentiment, translated by W.W. Holdheim. New York: Schocken.

Terzić, Z. (2022) Idiocracy: Thinking and Acting in the Age of the Idiot, translated by M. Turnbull. Berlin: Diaphanes.

Vogl, J. (2021) Kapital und Ressentiment: Eine kurze Theorie der Gegenwart. München: C.H. Beck.

Vogl, J. (2022) Capital and Ressentiment, translated by N. Solomon. Cambridge: Polity. 